\title{
參加印度“南亞栽培植物之起源及 分佈”討論會經過
}

吳徵鎑 侯學显

(中國科學院植物分颣研究所)

1 月 12 日至 15 日 在印京新德里舉行了一個 開於 “南亞栽培植物的來源及分佈”的討諭會 (Symposium)。此會係由印度遺傅育種學會主持 但得到聯合國交紋織UNESCO南亞科學合作館 South Asia Science Co-operation Office 的合作:

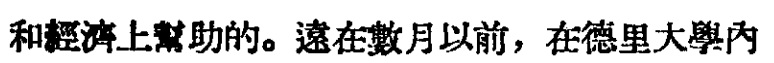
科棌合作馆中有一次非正式的集會, 組織這個討 論會的意思便被提出討論, “第的是總結一下在一 些截培作物上已做的工作並對分類, 細胞遺傅, 及有種等基礎方面的進一步工作引起一個刺激”。 其媵决定必需要一些專家殿問來寥加。於是由合 作儌邀請了英國曼徹斯特大篹教授，棉花育種家 S. C. Harland 及美國密蘇里植物園及華留頓大 㠘的数授，玉米育程家 Edgar Anderson。而瑞 典龍德 (Lund) 大學教授，小麥及黑麥專家 A. Müntzing 被邀也在寥加印度科學會議末次會挠 趕來。其他亞洲國家则有下列各储不同作物的工 作者寥加即錫闌的 M. F. Chandraratna 博士（香 蕉), 巴基斯坦的 Mohammad Afzae 及 M. A.

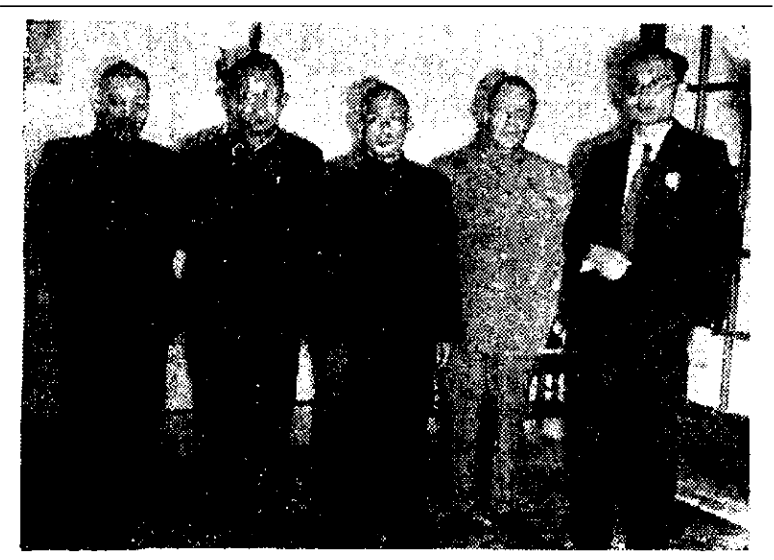

代表團與䮃印大使馆裳大使合影， 中立者第袁俳貫大使
Ansari (棉花) 二先生, 和新加坡的 R. E. Hol一 ttum 数授(栽唔灌科植物)。我國代表出席事係由 印度遺傅育種學會出面向科學院邀請, 然媵科學 院在通知有關方面推菣後州以委派者, 寥加者有 四人除我們二人外還有中心大學農林植物研究所

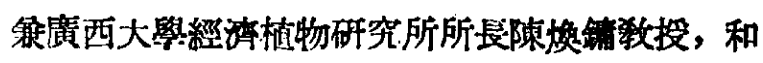
在印度勒克腦 Lucknow 古植物研究所 Birbal Sahni Institute of Palaeobotany 工作的徐仁数 授。由於事先對略會討論內容了解不的，我國代 表中未能包括作物育種舉者, 使我們在寥加道次 會中,對晾會所起的作用隇少許多。

我們於二日奉派, 三日晚繁程, 六日過衡陽 時遇陳焕鉡, 八曰離穗赴港, 十一日乘 PAA 飛弯 铝把機赴印, 十二日晨抵新德里, 與在印代表徐仁 會齊,正好趕上首次會中諭交開始宣渱。

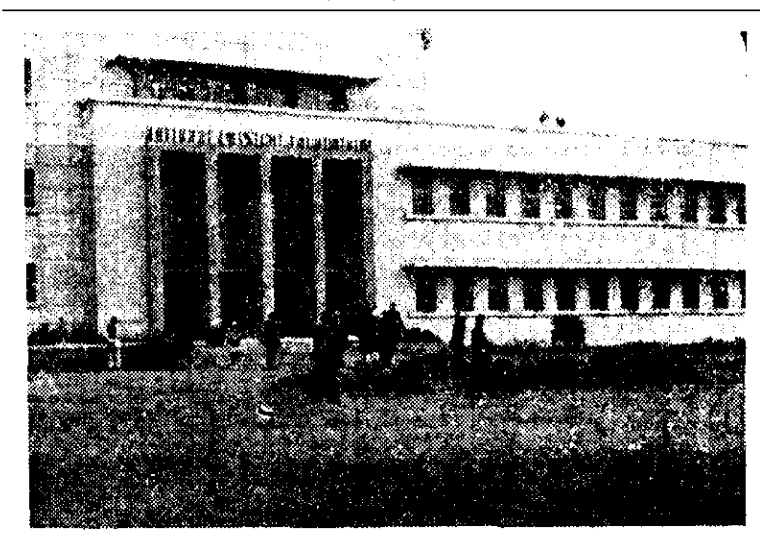

\section{德里國立物理研究所一矿論會會场}

這次會中, 印度參加者有十1四人，即津那Poona, Maharashtra 科學促進協會 Association for the Advancement of Science 植物研究空主任 S. P. Agharkar; 科因巴脫“Coimbatore，政打拉 斯省棉花推廣官 R. Balasubramanyam; 德里印 
度凑菜研究所所長 B. P. Pal 博士; 細胞遗傅

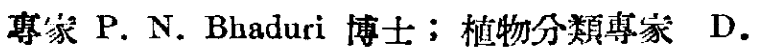
Chatterji 博士；遺傳專家 N. Parthasaratlyy 博 士;沚爾各答大學植物系教投 A. K. Chakravarti 博士；康坡 Kanpur，省立晨學院植物學教授 $\mathrm{K}$. N. Kaul 博士; 科因巴脫费學院及研究所的細胞 遺傅㝵家 N. Krishnaswamy 博士; S. Sampath 先生; 德里大學植物系講瑡 S. K. Mookherjee 博 士; 胡格里 Hooghly 黃藏裳業研究所所長 B. C. Kundu 博士; 巴特納 Patna 中央騳鈴薯研究所 所長 S. Ramonujam 溥士; 以及刻塔克 Cuttock, 中央稻作研究所所舆 K. Ramiah 博士。另有各

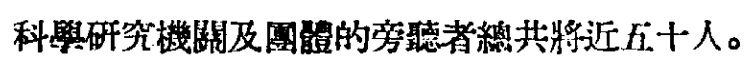

十二日及十五日兩天會場在國立物理望騟室 National Physical Laboratory, 十三日會在德里

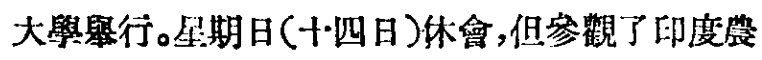
莱研究所植物部的寅驗地及博物館。關於芥荣、界 茄、小桨等的選種工作頗引人入勝。三日中所行論 的內容及日程如下:

十二日：稻、小麥、香蕉及杞果。

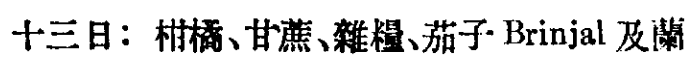
類。

十五日：棉花、黃满、芝脑、香料 (苗科)及、棕 桐類(椰子海慗等)。

前任印度頲傳選種轝會會長 K. Ramioh 博 士當選满主席。每日上下午均有會議，上午闒始

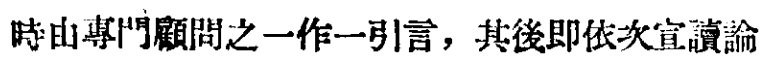
文, 㓡果皆有短短的討論, 三日共謮諭文二十一 篇。Harland 第一天發言談到作物“桃源中心” (分作中心)的各方面, “来源中心” 即各噇作物有

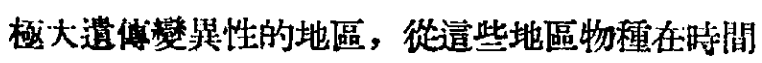
上和空間中移動而逐漸適應於變化的環境焂件。 此種適應常與“基因突變”及多套型 Polyploidy相 關聯。他很着重的提出到“裁培植物的來源中心” （分佈中心）去搜集野生相近種類有很大價值, 因 传在通些植物中有 “有望在價值” 的 “基因”。第 二天 Anderson 則指出植物品種發生中基本問題 的重要性，牠們常可有極大望用價值。他舉玉米篇 例，玉米雜交試驗中，對玉米節間各型的仔細研 究, 可以亩出從地面起有一定高度上長棒子的新

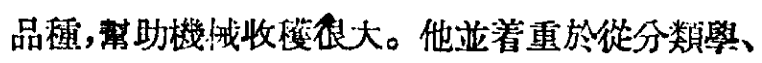
程源植物學 Ethnobotanical、細胞學及遗傅學各
方面來㸴究栽培植物的品種, 建議製造特殊型烒

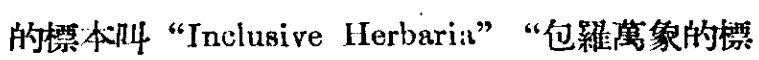
本”。Muntzing 在第三天的阙埸白也强調决等栽 培植物 “來源山心” 的重要。他又報告了瑞典各 個植物育程機構及植物惯駿空，其組䋘及對種称 研究計劃的配合，尤其在瑞典各㑬莱候帶的育程 工作中的配合。

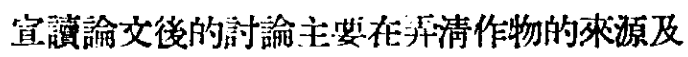
分倠的資料及概念，重要的有如下所述的。關於水 稻的来源中心認罢是奥利沙少 Orissa、孟加拉省 Bengal、阿薩密省 Assan 及緬甸暏地的四周, 同 時也就是甘䈚和茄子的來源中心。载培稻種Oryza sativa L. 是多元的. 從二至三種野稻發展出來。小 麥方面, 討論集中於展泛而複雜的種間及圈間雜 交, 亚對产生抗銹品種也有一湖稿法即需要從野

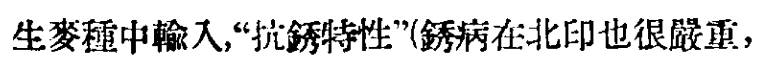
每年損失 20-crore 的虚比)。印緬恶来區則被証

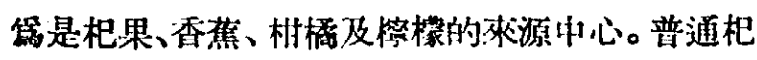
果認第是雜種來源, 是多套型的。無數品程都由 “基因笑變” gene mutation 從原型分化出來, 而 由焦性蕃殖法保存下来。香焦果整可吃是由於無

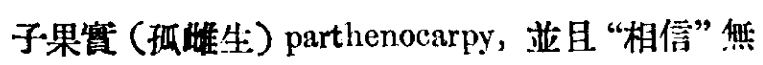
子果筫和焳性不㔔都是由可驾的管套 Musa acuminata 及 M. Balbisiana 經過团基突變而獲 得的。西坐球的與數栽培品種認学都是-經過許多

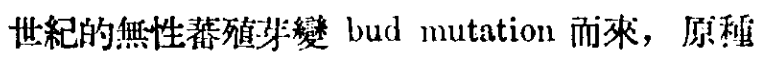
是少数起先是三套型的種苗。像阿陵密省則收集

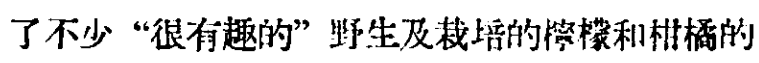
品種並且從形態學及園藝學上州以分類。北印上 生甘蕉被認经是由於雨整甘蕉（普通甘藻 Saccharum officinarum 及野生甘䔲 S. spontaneum) 廣泛自然雜交而産生的。甘蕉理極高度多晨化的 種, 其冝先的原種之一有 $\mathrm{n}=5$ 數的染色體, 一如 另一印座相近屬 Sclerostachya。希漹拉雅汕坡有 很多“有趣的” 型式可用來有成適 䭒於各個區域 的許多品種。

在中印南印盗療土壤上，有些小粒彭物例如 高粱 Pennisetum typhoideum 及小米, 頗永重 要, 其雜交及細胞學工作, 在科因巴脫城也在進 行。茄子則認篇是 Solanum incanum 及 S. melongena var. insanum 雜交而柬。其後逐漸被人

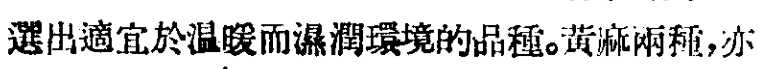


有闹樣道應情形。Corchorus olitorius (長果積)起 诸於非州，辟地可找到許多相近種, C. Capsularis (圆果程) 則似從印緬區域來, 但從馬來亞來也值

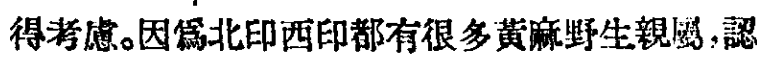
停育出品種適應於北印乾燥地區想來也有希望。

其餘關於印度术棉 Gossypium arboreum 起 源於非洲種 G. anoinalum, 芝㳜抗病品種的育成，

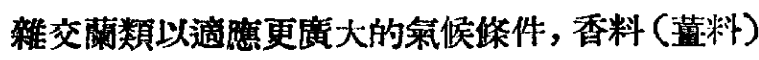
在震業起源上的歷史重要性等亦有報告。而關於 楖子及海霜之起源，則地質學的記錄和化不的證 㨜也有很大的得助。

最後证有四项建議: (一)輸入植物最好望從 有相似或近於相似的氣候或環境悠件的地區，所 以認篅在南亞區最好從墨西哥, 秘鲁及危地馬拉 鐱入植物。亚建議發展一㑬輸入植物的機椫。(二) 南亞各區經睍植物及其他相近野生植物的搜集调 查官成立一適當的國立的或國際的機構來推動。 （三）在植物研究中心中，育成良種的工作必須從 所有栽培植物及其相近種類的細胞遺傅和墢展生 理 (Developmental Physiology) 工作兩方面入 手。(约) 栽培植物分類學上的進步也很需婆, 栽 培作物的所有品系都須慗成 “Inclusive Herbaria”，湴且在各個植物育種中心中储放。

在最挠一天下午開會前由德里大學植物生理

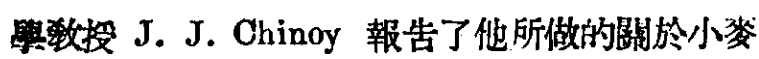
春化試驗的成功結:果, 並以數學來證明 光温 量 Photo-temperature Quanta 與植物階段 Veget:tive period 的本方反比關係。

綜上所进,此次會議的內容, 主要是從細胞遗 傅學及植物地理學入手。所取基本觀念是與曼德 爾摩爾根一派互相呼應的, 有些勋骤然是 I. N. Vavilov 燢證的翻版, 與 Julian Huxley 所著新 分類學New Systematics 中所用方法也頗多相同。 這些觀點和方法, 在蘇聯是已被李森科所批挑的 了。我們因均非遺傳有種專家，他們也未對米邱 林、李森科提出正面政繁。所以我們只表示了沈默 的懹疑態度, 未予附和但亦未作激烈的批制, 只是 有些時候强萑周一下環境佟件的棕合影響，所謂來 源中心的不可靠性以及算際上㷛用等情形。

開會期間，留由陳煥錴團長代表科學院致詞 的钨諭會成功亚說: “可以碓定, 我們雨國間的科 學合作定會推進全严洲人民的福利及䇣，希堂
印度及中國植物學者此後可以携起手來密切合作 共同向科學的進步方面造進。我們人民間的團結 合作萬藏。”

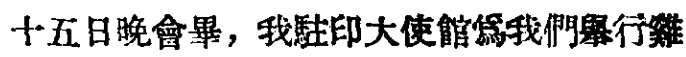
尾酒會招待德里重要科翼家、與會諸專家、研究部

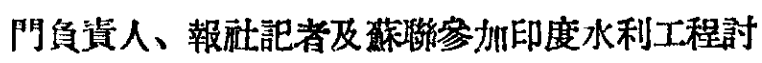
諭會睢問圆等的共百餘人,賓主交際甚歡,均對新 中國政府重視科學和科學家的煳形很感興奪, 希

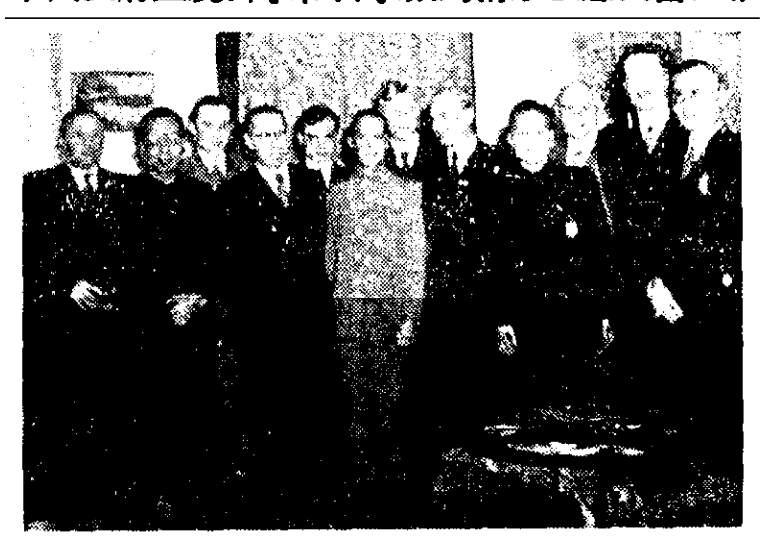

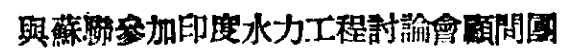
合摽於大使管曾密害中

媓中印科學交化交流合作。英、美、錫蘭、新加坡等 處專家也都來公加, 瑞典夏家因該國大使館宴請

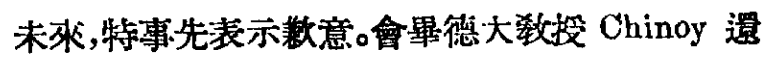
留下桃和我們進行同樂會, 依依不唅。

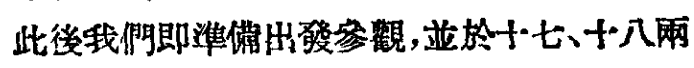
日在德里寥觀農粪研究所及德大植物系。也附需 参觀了印度政府舉辦的國際工菜展筧會兩次, 此

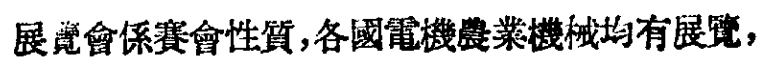

(2).

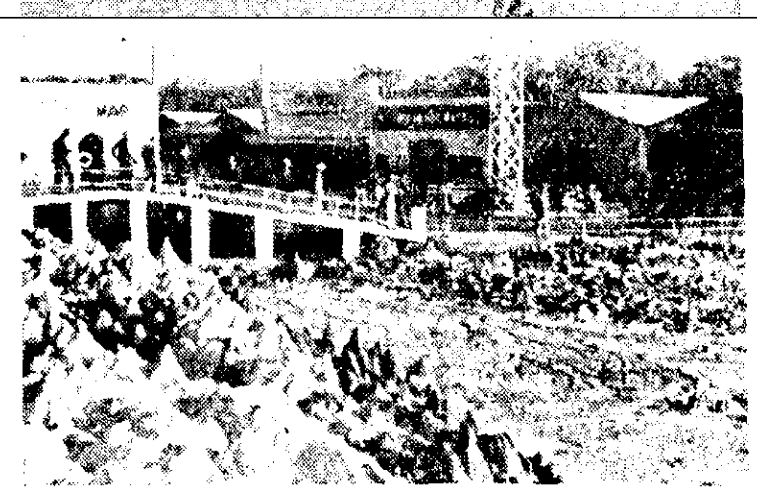

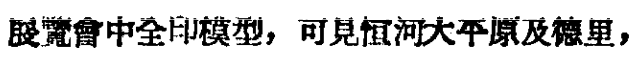
白者筑希馬拉雅山

但大多數係水利工程設計，其中有些規模相當宏 大,但在現階段,䏌有大多数係空中樓閣。關於术 政工程,理想家庭的設計,有些有似乎证離了印度 的嵔際，入門處巨大的全印地形模型倘富有教有 
窟新,也很吸引人。

此後日程大致如下:

\#日至甘十日:自德里飛加爾各答，亚在加留

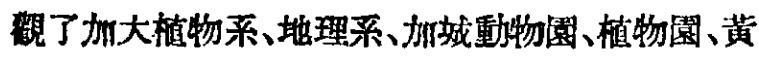

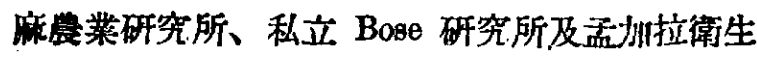

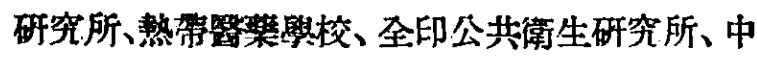

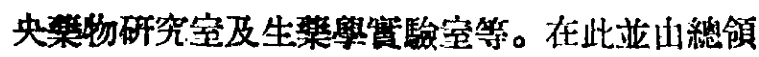
事館招待曅僑代表茶會一次。䌖尾酒會一次招待 加城重要科學家、報社記者等九十餘人，是晚名科 燢家如物理燢家 Saha、生物化學家 Guha、植物 舁家 Biswas, 生物物理學家 Bose 等均行出席。 西孟加拉省省督並自䄇出席, 親自和我們交談。

甘八刀:自加成我窥打拉斯 Madras，參觀麻 打拉斯大㠘植物系貨驗室。

\#九日至册日：自麻城飛科因巴脫 Coimba-

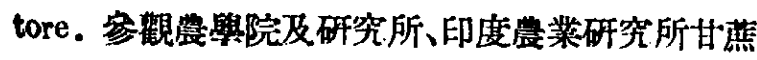
育種站、麻省林舉院。亚附帶參觀了G. D. Naidu 的工業展㹂宝、Arthus Hope 高級工業學校、聯合 托公司、農場、以及 Nair 家族的紡秒做、農場 等。Naidre 有大規模菒會招待,陳團長作演講一 次。我等三人又在费藇院演講一次。

册一日至二月四日：自科城屃班加諾 Bangalore。參觀 Central College 之植物系及裳學系 農學院印度科學研究所、Lal Bagh 植物園、私立 C. V. Ranan 研究所。四日並赴近郊南底 Nandi 小山游筧探集並部問農村。在科研所,陳團長曾作 報告一次。

二月五日至六日：續我蒲那 Poona 參觀農

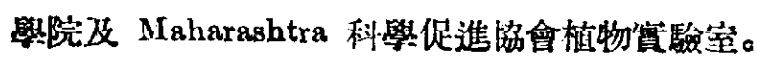

大日至八日：火車赴盖買 Bombay，㫃観印

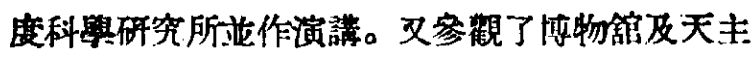
私立 St. Xavier College 中的標本定。以媵在

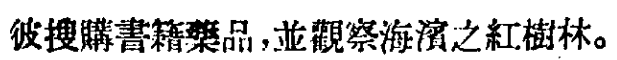

九日飛回德里,夜車赴德拉東 Dehra Dun.

十百十六日: 在德拉東参観森林研分所, 中 間會至希馬拉雅山㭸避瑟名勝 Mussoorie 游筧-D 日，至附近茶園寥觀茶樹之種植及製茶。赴沙哈的 坡揢觀 Taungya 造林區域。在此並曾向林繁院及 理舉院師生演講一次。上述度次講演內容多保介 櫂科學院的一般原则, 工作方向, 以及研究機構

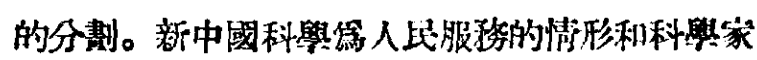
興奮工作的情形。有時也介紹一些中國人民在清 林生产方面的經驗例如等高線帶狀造林法, 用人 烡做肥料等。大多數均結合他們所發的問題談一 些關於糧食㙁座，教授學生生活問題等。

十六日夜車返德里。以後在德里候飛機及签

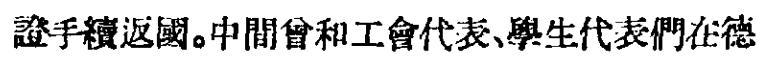

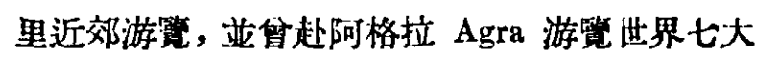
奇䠝之一回教王妃境 Taj Mahal 等滤二日。

三月二日自德里起我，三日抵港，在港寥颉港 大及香港植物園，文赴儿龍及香港山项探集游筧。 七日自港返穗,參觀中山大學及篢南大學。十吙日 自㗭北返，十七日抵京。

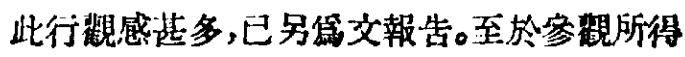

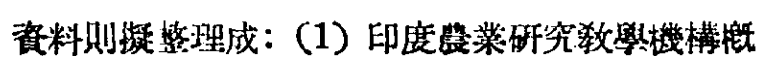

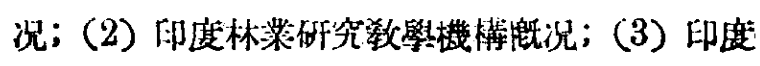
的一般科學研究的情形; (4) 印度袖物學研究的

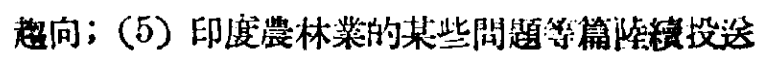
科學通報：以资介紹。

\section{我國際竪療隊抵達朝鮮}

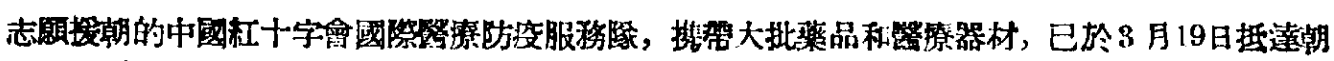

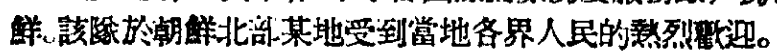

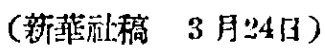

